\title{
ADRENAL CORTICAL $11 \beta$-HYDROXYLASE AND SIDE-CHAIN CLEAVAGE ENZYMES. REQUIREMENT FOR THE A- OR B-PYRIDYL RING IN METYRAPONE FOR INHIBITION
}

\author{
Michael C. Tobes*, Sheryl J. Hays $\dagger$, David L. Gildersleeve, Donald M. Wieland and \\ William H. Beierwaltes \\ Division of Nuclear Medicine, Department of Internal Medicine, The University of Michigan Medical \\ Center, Ann Arbor, MI 48109, U.S.A.
}

(Received 14 January 1984)

\begin{abstract}
Summary - The adrenal cortical enzyme systems, $11 \beta$-hydroxylase, $\mathrm{P}-450_{11 \beta}$, and the side-chain cleavage complex, P-450 scc, differ only in their cytochrome P-450s. Structural modifications of metyrapone, an inhibitor of cytochrome P-450 enzyme systems, have been made to determine the requirement for the Aor B-pyridyl ring for inhibition of $\mathrm{P}-450_{1 / \beta}$ and $\mathrm{P}-450 \mathrm{scc}$ activities. Three new analogs of metyrapone (A-phenylmetyrapone, B-phenylmetyrapone and diphenylmetyrapone) were synthesized and evaluated as inhibitors using a crude, defatted bovine adrenal cortical mitochondrial preparation. Characterization of the mitochondrial preparation demonstrated: (1) enhancement of both activities by the addition of $15.0 \mu \mathrm{M}$ adrenodoxin, (2) the addition of $1 \%$ ethanol decreased both activities less than $10 \%$, and (3) the apparent $K_{\mathrm{m}}$ of deoxycorticosterone for $\mathrm{P}-450_{118}$ was $6.8 \mu \mathrm{M}$ and the apparent $K_{\mathrm{m}}$ of cholesterol for $\mathrm{P}-450 \mathrm{scc}$ was $21.6 \mu \mathrm{M}$. Inhibition of $\mathrm{P}-450_{11 \beta}$ and $\mathrm{P}-450 \mathrm{scc}$ activities with these compounds demonstrated: (1) the B-pyridyl ring of metyrapone is required for inhibition of both activities whereas requirement for the A-ring is less stringent, and (2) the four metyrapone analogs were more selective inhibitors of P-450 $11 \beta$ activity. These studies suggest that the A-phenyl metyrapone analog is a good candidate for further development of a selective adrenocortical radiopharmaceutical.
\end{abstract}

\section{INTRODUCTION}

The adrenal cortex has a unique enzymatic pattern that is directed towards the synthesis of various steroids from cholesterol $[1,2]$. Of the enzymes in these pathways, both the $11 \beta$-hydroxylase and the side-chain cleavage enzyme systems are found almost exclusively in the adrenal cortex $[1,2]$. The $11 \beta$-hydroxylase enzyme system, $\mathrm{P}-450_{11 \beta}$, can catalyze the $11 \beta-, 18-$, and 19-hydroxylations of various types of steroids [3-5], however, P-450 $11 \beta$ activity is usually characterized with the substrate 11-deoxycorticosterone (DOC). The side-chain cleavage enzyme system, P-450 scc, catalyzes the sidechain cleavage of cholesterol to pregnenolone $[2,6]$. Both enzyme systems are similar in that they are composed of: (1) adrenodoxin reductase, a flavoprotein, (2) adrenodoxin, an iron-sulfur protein, and (3) cytochrome P-450, a heme protein. However, the cytochrome P-450s of the two enzyme systems are immunologically distinct [4].

*All correspondence should be sent to: Michael C. Tobes, Division of Nuclear Medicine, Department of Internal Medicine, R4601 Kresge Medical Research I, The University of Michigan Medical Center, Ann Arbor, MI 48109, U.S.A.

†Present address: Warner-Lambert Company, Pharmaceutical Research Division, 2800 Plymouth Road, Ann Arbor, MI 48105, U.S.A.
Metyrapone (Table 1), 2-methyl-1,2-di-(3-pyridyl)1-propanone, is a pyridine derivative that has been widely used to determine pituitary ACTH reserve $[2,3,7,8]$. Metyrapone inhibits the activity of various cytochrome P-450 requiring enzyme systems by reversibly binding to the specific cytochrome P-450's $[3,7,9-13]$. Of the four major cytochrome P-450 requiring enzyme systems within the adrenal cortex, the mitochondrial enzymes, P-450 $0_{11 \beta}$ and P-450 scc, have been reported to be inhibited by metyrapone $[3,13-16]$ whereas the microsomal enzymes, the steroid 21 -hydroxylase and the $17 \alpha$-hydroxylase were reported not to be inhibited by metyrapone [13,15-18]. This is apparently the case for the enzymes in the adrenal cortex of man, bovine and rat, but some species differences are suggested by the report of metyrapone binding to the adrenal cortical microsomes in the guinea pig [18]. Metyrapone, however, has been primarily shown, both in vivo and in vitro, to be more specific for the inhibition of $\mathrm{P}-450_{11 \beta}$ activity $[1,2,3,7]$.

We have been interested in developing a radioiodinated metyrapone analog that would concentrate in the adrenal cortex based on its selective inhibition of $\mathrm{P}-450_{11 \beta}$ activity [19]. A program has been undertaken to systematically alter the structure of the metyrapone molecule to probe those structural features necessary for the differential inhibition of P-450 $0_{11 \beta}$ and P-450 scc. Another objective is to deter- 
Table 1. Structure-activity relationship study: requirement for the A- or B-pyridyl ring in metyrapone for inhibition of bovine adrenal cortical mitochondrial P-450

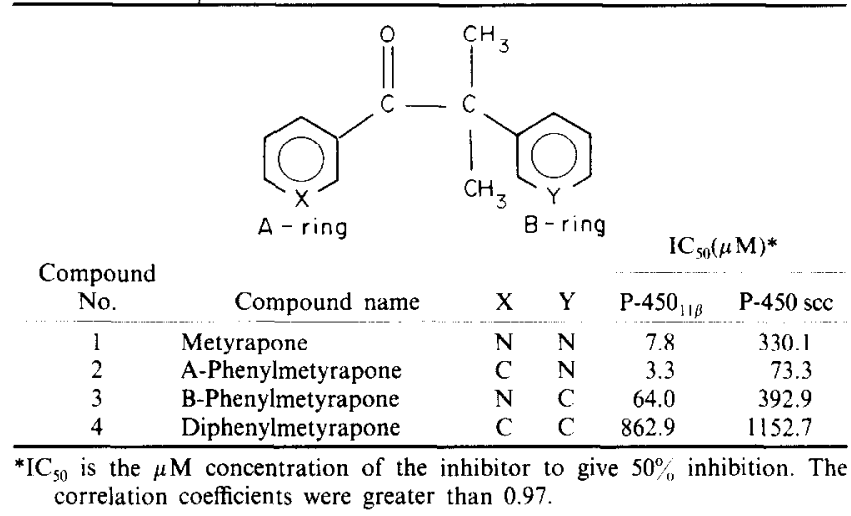

mine the optimal site for incorporation of an iodine atom which still maintains this differential inhibition. In this study, we have investigated the requirement for the A- or B-pyridyl ring of metyrapone for inhibition of the two activities by systematically substituting the pyridyl rings with phenyl rings without altering the rest of the metyrapone structure (Table 1).

For this study, we wanted to use a simple preparation, containing both $\mathrm{P}-450_{11 \beta}$ and $\mathrm{P}-450 \mathrm{scc}$ activities, to evaluate the metyrapone analogs. We, therefore, decided to use a crude, defatted bovine adrenal cortical mitochondrial preparation as previously described [14]. Attempts to use this preparation were unsuccessful due to little enzymatic activity in the preparation. We, therefore, report the characterization of a simple adrenocortical preparation for the rapid screening of inhibitors of $\mathrm{P}-450_{1 \mid \beta}$ and $\mathrm{P}-450 \mathrm{scc}$ activities. Using this preparation, we determined that the A-pyridyl ring of metyrapone replaced with a phenyl ring would be a good candidate for radioiodination.

\section{Chemicals, radiochemicals and materials}

The following chemicals were purchased from Sigma Chem. Co., St Louis, MO: bovine serum albumin (BSA), corticosterone, DOC, 18-hydroxyDOC, EDTA, cholesterol, pregnenolone, progesterone, NADPH, Tween-20, Sephadex LH-20-100, Sephadex G-75-120, DEAE-cellulose and DEAESephacel. $N, N$-dimethylformamide was obtained from Mallinckrodt, St Louis, MO; dithiothreitol from Calbiochem-Behring, San Diego, CA; Whatman K6F silical gel glass TLC plates, $20 \times 20 \mathrm{~cm}$, $250 \mu$, from Anspec Co., Ann Arbor, MI; Econocolumns, polypropylene, $0.8 \times 4.0 \mathrm{~cm}$, from Bio$\mathrm{Rad}$, Richmond, $\mathrm{CA}$; and polypropylene tubes (Falcon), $12 \times 75 \mathrm{~cm}$, from American Scientific Products, McGaw Park, IL. Trilostane (WIN-25, 540: $2 \alpha$-cyano-4 $\alpha, 5$-epoxy-17 $\alpha$-hydroxy-androstane-3-one) was a generous gift from Sterling Winthrop Co., New York. Ethyl nicotinate, benzyl cyanide, tertbutanol, potassium tert-butoxide, methylene chlor- ide, acetonitrile, propylene glycol and acetone were purchased from Aldrich Chemical Co., Milwaukee, WI. All other chemicals were the best commercially available grades.

The following radiochemicals were obtained from New England Nuclear, Boston, MA: $\left[1,2-{ }^{3} \mathrm{H}(N)\right]$ DOC, $41.8 \mathrm{Ci} / \mathrm{mmol} ; \quad\left[1,2-{ }^{3} \mathrm{H}(N)\right]$ corticosterone, $40.0 \mathrm{Ci} / \mathrm{mmol} ;\left[1,2-{ }^{3} \mathrm{H}(N)\right]$ cholesterol, $40.7 \mathrm{Ci} / \mathrm{mmol}$; and $\left[4-{ }^{14} \mathrm{C}\right]$ pregnenolone, $55.7 \mathrm{mCi} / \mathrm{mmol}$. Liquifluor, the PPO-POPOP toluene concentrate, was also purchased from New England Nuclear.

\section{Metyrapone analogs}

Elemental analyses were performed by Spang Microanalytical Laboratory, Eagle Harbor, Michigan. Infrared spectra were recorded on a Beckman IR Aculab 8 spectrophotometer. Nuclear magnetic resonance spectra were recorded on a Varian EM$360 \mathrm{~A}$ spcctrophotometer. Ultraviolet spectra werc recorded on a Beckman Model 35 Dual Beam UV/Visible spectrophotometer. All melting points were taken on a Laboratory Devices Mel-temp capillary melting point apparatus and are uncorrected.

Metyrapone (2-methyl-1,2-di-(3-pyridyl)-1-propanone), compound 1, was a generous gift from CibaGeigy, Inc., Summit, NJ. The A-phenylmetyrapone (2-methyl-1-phenyl-2-(3-pyridyl)-1-propanone), compound 2, was synthesized as described by Hays et al.[19]. Diphenylmetyrapone (2-methyl-1,2-diphenyl-1-propanone), compound 4 , was synthesized as described by Landgrebe and Kirk[20].

B-Phenylmetyrapone (2-methyl-2-phenyl-1-(3pyridyl)-1-propanone), compound 3 was synthesized by a three step synthesis. Ethyl nicotinate, and benzyl cyanide, were treated with sodium ethoxide in absolute ethanol to yield the enol, which was hydrolysed and decarboxylated to produce the ketone as first described by Burger and Walter[21]. The hydrobromide salt of ketone $(1.0 \mathrm{~g}, 0.0036 \mathrm{~mol})$ was dissolved in $20 \mathrm{ml}$ tert-butanol under an argon atmosphere with mechanical overhead stirring. Potassium tert-butoxide $(1.23 \mathrm{~g}, 0.011 \mathrm{~mol}, 3.05 \mathrm{eq}$.) was added and the solution turned a bright yellow and was 
heated to $85^{\circ} \mathrm{C}$ for $5 \mathrm{~h}$. Methyl iodide $(1.12 \mathrm{~g}, 0.49 \mathrm{ml}$, $0.0079 \mathrm{~mol}, 2.2 \mathrm{eq}$.) was added to $2 \mathrm{ml}$ tert-butanol and the solution was added dropwise over a $1 \mathrm{~h}$ pcriod. The reaction was heated and stirred an additional $18 \mathrm{~h}$. The reaction was cooled and partitioned between water and methylene chloride. The methylene chloride layer was dried, filtered and concentrated under reduced pressure. The residue $(0.71 \mathrm{~g})$ was placed on a silica gel column $(15 \times 130 \mathrm{~mm})$ and eluted with $200 \mathrm{ml}$ ethyl acetate-methylene chloride $(1: 19 \mathrm{v} / \mathrm{v})$. The residue $(0.60 \mathrm{~g})$ was taken up in $1.0 \mathrm{ml}$ acetonitrile and chromatographed on a Whatman Partisil M9, $10 \mathrm{~mm} \times 50 \mathrm{~cm}$, ODS-2, reverse phase preparative HPLC column, eluted with wateracetonitrile $(4.5: 5.5, \mathrm{v} / \mathrm{v})$ at a flow rate of $10 \mathrm{ml}$ per min. 2-Phenyl-1-(3-pyridyl)-1-propanone was eluted and collected from the column first followed by the desired compound 3 with retention times of 8.32 and $11.92 \mathrm{~min}$ respectively. After removal of the acetonitrile, the aqueous eluant was extracted with methylene chloride. The methylene chloride layer was dried, filtered and concentrated under reduced pressure to yield the dimethyl ketone $(0.176 \mathrm{~g}, 21.7 \%)$ as a clear oil. The infrared spectra (neat) was $1675 \mathrm{~cm}^{-1}$ $(\mathrm{C}=0), 1384,1362$ (gem dimethyl). The ${ }^{1} \mathrm{H}$ nuclear magnetic resonance spectra $\left(\mathrm{CDCl}_{3}\right)$ was $\sigma 1.59$ $\left(\mathrm{s}, 6 \mathrm{H}, \mathrm{CH}_{3}\right), 7.07(\mathrm{~m}, 1 \mathrm{H}$, aromatic) $7.32(\mathrm{~s}, 5 \mathrm{H}$, aromatic), $7.76(\mathrm{~m}, 1 \mathrm{H}$, aromatic), and $8.56(\mathrm{~m}, 2 \mathrm{H}$, aromatic). The product was converted to its bright yellow picrate salt (melting point of $127-128^{\circ} \mathrm{C}$ ) for elemental analysis. Analysis calculated for $\mathrm{C}_{15} \mathrm{H}_{15} \mathrm{NO} \cdot \mathrm{C}_{6} \mathrm{H}_{3} \mathrm{~N}_{3} \mathrm{O}_{7}: \mathrm{C}, 55.51 ; \mathrm{H}, 3.99$; and $\mathrm{N}$, 12.33. Found: $\mathrm{C}, 55.58 ; \mathrm{H}, 4.05$; and $\mathrm{N}, 12.38$. The monomethylated ketone $(1.74 \mathrm{~g}, 23.2 \%)$, as described by Napoli and Counsell [14], was also isolated.

Preparation of the crude, defatted bovine adrenal cortical mitochondrial P-450 enzymes

Adrenal cortical mitochondria were isolated, lyophilized, and defatted by a modification of the methods of Nedergaard and Canon[22] and Napoli and Counsell[14]. Bovine adrenal glands were obtained fresh from a local slaughterhouse. Cortical tissue was cleaned free of fat, capsule and connective tissue and separated from medulla. The tissue was diced and homogenized $(1: 10)$ in $0.25 \mathrm{M}$ sucrose containing $10 \mathrm{mM}$ potassium phosphate buffer, $\mathrm{pH}$ $7.40,0.10 \mathrm{mM}$ EDTA, $0.5 \%$ BSA, and $0.5 \mathrm{mM}$ dithiothreitol at $4^{\circ} \mathrm{C}$. The homogenate was centrifuged at $1,000 \mathrm{~g}$ for $10 \mathrm{~min}$ at $5^{\circ} \mathrm{C}$ in a Beckman J-21 $\mathrm{C}$ centrifuge. After filtration through cheesecloth, the supernatant was centrifuged at $10,000 \mathrm{~g}$ for $10 \mathrm{~min}$. The resultant mitochondrial pellet was washed twice with homogenization buffer and the washed pellet was resuspended into $10 \%$ of the original volume of homogenization buffer without EDTA, BSA, or dithiothreitol. This suspension was lyophilized, and the evacuated flasks were flushed with argon and stored in a dessicator at $-50^{\circ} \mathrm{C}$. The moisture-free mitochondrial powder was homogenized in cold acetone, $-20^{\circ} \mathrm{C},(250 \mathrm{mg}$ powder per $25 \mathrm{ml})$ to extract endogenous steroids and centrifuged at $20,000 \mathrm{~g}$ for $5 \mathrm{~min}$ at $-5^{\circ} \mathrm{C}$. The pellet was washed twice with the same volume of cold acetone. The precipitate was collected by vacuum filtration and dried under $\mathrm{N}_{2}$, followed by dessication in vacuo over potassium hydroxide at $-50^{\circ} \mathrm{C}$. Immediately prior to use, the acetone powder was reconstituted by suspension into $30 \%$ propylene glycol $(12.0 \mathrm{mg}$ powder per $400 \mu 1)$ by homogenization at $4^{\circ} \mathrm{C}$. Using the method of Peterson[23] with BSA as the standard, the protein content of the acetone powder was determined to be $1.64 \mathrm{mg}$ protein per $12.0 \mathrm{mg}$ of the acetone powder.

\section{Preparation of the purified adrenodoxin}

Adrenodoxin was purified by a modification of the methods of Kimura and Suzuki[24] and Kimura et al.[25]. All procedures were carried out at $5^{\circ} \mathrm{C}$ unless stated otherwise. All buffer solutions were $10 \mathrm{mM}$ sodium phosphate, $\mathrm{pH} 7.40$, containing either 0,170 , 300 or $500 \mathrm{mM}$ potassium chloride $(\mathrm{KCl})$. Bovine adrenal cortical tissue, approx $0.5 \mathrm{~kg}$, was homogenized and centrifuged to give a $3000 \mathrm{~g}$ supernatant in $170 \mathrm{mM} \mathrm{KCl}$ buffer. After filtering through cheesecloth and diluting with $2.4 \mathrm{vol}$ of cold deionized and redistilled water, $10 \mathrm{~g}$ of washed DEAE-cellulose was added to the diluted supernatant, and the suspension was stirred for $18 \mathrm{~h}$. The DEAE-slurry was transferred by siphon under 5 psi of $\mathrm{N}_{2}$ to a $6.0 \times 15.0 \mathrm{~cm}$ column where it was filtered through glass wool. After washing the packed DEAE-cellulose column with 1.01 . of $170 \mathrm{mM} \mathrm{KCl}$ buffer, the adrenodoxin was eluted with $200 \mathrm{ml}$ of $500 \mathrm{mM} \mathrm{KCl}$ buffer.

The pooled adrenodoxin was diluted with $2.0 \mathrm{vol}$ of buffer with no $\mathrm{KCl}$ and applied onto a DEAESephacel column $(5.0 \times 30.0 \mathrm{~cm})$ which was equilibrated with $170 \mathrm{mM} \mathrm{KCl}$ buffer. After eluting the column with 1.5 column vol of the $170 \mathrm{mM} \mathrm{KCl}$ buffer, the adrenodoxin was eluted with $300 \mathrm{mM} \mathrm{KCl}$ buffer at the rate of approx $50 \mathrm{ml}$ per h. Fractions of $10 \mathrm{ml}$ were collected. The active fractions were pooled and concentrated to approx $10 \mathrm{ml}$ by ultrafiltration in a 402-ml and then a 52-ml Diaflo cell with a YM-5 membrane (Amicon Corp., Lexington, MA) at a working pressure of $20 \mathrm{psi}$ of $\mathrm{N}_{2}$.

The concentrated enzyme solution was applied to a G-75 Sephadex column $(3.0 \times 100.0 \mathrm{~cm})$ which was equilibrated with buffer with no $\mathrm{KCl}$. The adrenodoxin was eluted with buffer at a rate of $40 \mathrm{ml}$ per $h$. Fractions of $5 \mathrm{ml}$ were collected. The active fractions were pooled, lyophilized and stored in a dessicator at $-50^{\circ} \mathrm{C}$. The final preparation was approx $90 \%$ homogeneous with an $\mathrm{A}_{414}-\mathrm{A}_{276}$ ratio of 0.770 . The yield was approx $100 \mathrm{mg}$.

\section{Assay of $P-450_{11 \beta}$ activity}

This cytochrome P-450 requiring enzyme system was assayed with DOC as the substrate by a modification of the method of Sato et al.[3]. Using $5 \mathrm{ml}$ polypropylene tubes, the reaction mixture, 
$0.50 \mathrm{ml}$, was modified to contain $50 \mathrm{mM}$ potassium phosphate buffer, pH $7.40,200 \mu \mathrm{M} \mathrm{DOC}(0.10 \mu \mathrm{Ci}$ $\left.\left[1,2-{ }^{3} \mathrm{H}(N)\right] \mathrm{DOC}\right), \quad 16 \mathrm{mM}$ magnesium chloride, $1.5 \mathrm{mM}$ NADPH, $4.6 \%$ propylene glycol, $15.0 \mu \mathrm{M}$ adrenodoxin, and $300 \mu \mathrm{g}$ of the crude, defatted mitochondrial preparation. The reaction mixture was preincubated at $37^{\circ} \mathrm{C}$ for $5 \mathrm{~min}$, and the reaction was initiated by the addition of NADPH and incubated for various times at $37^{\circ} \mathrm{C}$. Reaction controls were done in the absence of NADPH or in the presence of a heat-inactivated mitochondrial preparation where the preparation was heated at $80^{\circ} \mathrm{C}$ for $3-5 \mathrm{~min}$. The reaction was terminated by the addition of $3.0 \mathrm{ml}$ of methylene chloride containing $5 \mu \mathrm{g} / \mathrm{ml}$ each of DOC and corticosterone and vortexed for $30 \mathrm{~s}$. After extracting and discarding the aqueous phase, the organic phase was dried down overnight at $30^{\circ} \mathrm{C}$ under room atmosphere.

The residue was re-extracted with $100 \mu \mathrm{l}$ of $100^{\circ}$ methanol and applied onto Whatman $\mathrm{K} 6 \mathrm{~F}$ silica gel glass TLC plates $(20 \times 20 \mathrm{~cm}$ plates, $250 \mu$, that were divided into $10 \times 20 \mathrm{~cm}$ sections and prescored to $10 \times 2.5 \mathrm{~cm}$ ) using the AIS TLC Multi-spotter ${ }^{\text {TM }}$. The plates were developed in chloroform-acetone $(5: 1$, $\mathrm{v} / \mathrm{v}$ ) for $20 \mathrm{~min}$ at $25^{\circ} \mathrm{C}$. The addition of DOC and corticosterone in the methylene chloride solution used to terminate the reaction permitted detection of the compounds under short wave ultraviolet light. Clear separation of DOC and corticosterone without overlap was obtained with the $R_{\mathrm{f}}$ values of 0.66 and 0.21 for DOC and corticosterone, respectively. The 18-hydroxy-DOC was not separated from corticosterone with this solvent system. Each zone was scraped and placed into a liquid scintillation vial. Methanol, $0.50 \mathrm{ml}$, was added to extract the ${ }^{3} \mathrm{H}$-labeled steroid from the silica. After the addition of $10 \mathrm{ml}$ of scintillant, the vials were mixed well and counted in a Beckman LS 7500 microprocessor controlled liquid scintillation system. The samples were counted for $10 \mathrm{~min}$ or to the preset error of $0.50 \%$. The overall recovery for the methylene chloride extraction was $99 \%$ and for the methanol re-extraction was $72 \%$. The amount of product formed was calculated as described where a unit of activity is defined as a pmole of DOC converted to corticosterone or 18-hydroxy-DOC per min at $37 \mathrm{C}[3]$.

\section{Assay of P-450 sce activity}

This cytochrome $\mathrm{P}-450$ requring enzyme system was assayed by a modification of the radiometric method of Takikawa et al.[6] and Hanukaglu and Jefcoate[26,27]. Using $5 \mathrm{ml}$ polypropylene tubes, the reaction mixture, $0.20 \mathrm{ml}$, was modified to contain $25 \mathrm{mM}$ potassium phosphate buffer, $\mathrm{pH} 7.20$, $200 \mu \mathrm{M}$ cholesterol $\left(0.10 \mu \mathrm{Ci}\right.$ of $\left[1,2-{ }^{3} \mathrm{H}(N)\right]-$ cholesterol), 1.0 mM NADPH, $1.5 \%$ propylene glycol, $1.25 \% \mathrm{~N}, \mathrm{~N}$-dimethylformamide, $0.30 \%$ Tween$20,15.0 \mu \mathrm{M}$ adrenodoxin, and $300 \mu \mathrm{g}$ of the crude, defatted mitochondrial preparation. The reaction mixture was preincubated at $37^{\circ} \mathrm{C}$ for $5 \mathrm{~min}$, and the reaction was initiated by the addition of NADPH and incubated for various times at $37^{\circ} \mathrm{C}$. Reaction controls were done in the absence of NADPH or in the presence of a heat-inactivated mitochondrial preparation in which the preparation was heated at $80^{\circ} \mathrm{C}$ for 3-5 min. The reaction was terminated by the addition of $200 \mu \mathrm{l}$ of $100 \%$ ethanol containing $1.0 \mathrm{nCi}$ of $\left[4-{ }^{14} \mathrm{C}\right]$ pregnenolone as a recovery standard. The steroids were extracted with $2.0 \mathrm{ml}$ of methylene chloride. After drying, the residue was re-extracted with $200 \mu \mathrm{l}$ of $40 \%$ methanol, and separated on Sephadex LH-20 in polypropylene minicolumns [26]. The eluted pregnenolone was collected in a liquid scintillation vial, and the methanol solution was evaporated. After the addition of $10 \mathrm{ml}$ of scintillant, the vials were mixed well and counted in a Beckman LS 7500 microprocessor controlled liquid scintillation system. The samples were counted for $10 \mathrm{~min}$ or to a preset error of $0.50 \%$. The ${ }^{3} \mathrm{H}$ channel was set at $0-397$ and the ${ }^{14} \mathrm{C}$ channel was set at $397-655$. The ${ }^{14} \mathrm{C}$ overlap into the ${ }^{3} \mathrm{H}$ channel was about $8 \%$. The overall recovery for the methylene chloride extraction was $86 \%$ and for the methanol re-extraction was $71 \%$. The amount of product formed was calculated as described where a unit of activity is defined as a pmole of cholesterol converted to pregnenolone per $\min$ at $37^{\circ} \mathrm{C}[6,26,27]$.

\section{Kinetic and inhibition studies}

Kinetic studies were done in the presence of $1.0 \%$ ethanol for the determination of the $K_{\mathrm{m}}$ of DOC for P-450 $11 \beta$ activity and for the $K_{\mathrm{m}}$ of cholesterol for P-450 scc activity. The kinetic studies were analyzed by the mathematical form of the Lineweaver-Burk double-reciprocal equation. The $K_{\mathrm{m}}$ values are the mean of three separate determinations.

Stock solutions of the inhibitors were made in $100 \%$ ethanol. Inhibitors were added to the reaction mixtures of each assay prior to the addition of NADPH such that a final concentration of $1 \%$ ethanol was added. Using controls in the presence of $1 \%$ ethanol, the percent inhibition, at varying concentrations of each inhibitor, was calculated. The $\mathrm{IC}_{50}$ $(\mu \mathrm{M})$ values were obtained from the linear portion of semi-logarithmic plots of percent inhibition vs concentration. Two separate determinations with five or more inhibitor concentrations were evaluated in triplicate in all $\mathrm{IC}_{50}(\mu \mathrm{M})$ determinations. Regression lines were calculated by least square analyses and the correlation coefficients were greater than 0.97 .

\section{RESULTS}

\section{Effect of added adrenodoxin}

A crude, defatted bovine adrenal cortical mitochondrial preparation was used so that both activities might be studied without purification of the protein components of these enzyme systems. However, adrenodoxin is a loosely bound mitochondrial protein 

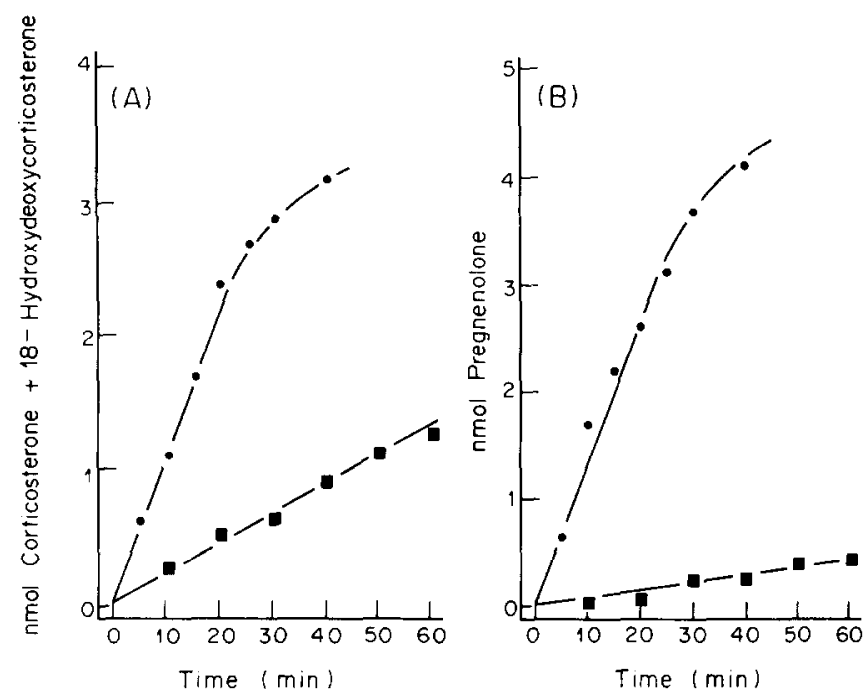

Fig. 1. Effect of added adrenodoxin to a defatted bovine adrenal cortical mitochondrial preparation on P-450 $11 \beta$ and P-450 scc activities. A. P-450 ${ }_{11 \beta}$ activity, in the absence $(-\square-$ ) or presence $(-\longrightarrow$ of $15.0 \mu \mathrm{M}$ adrenodoxin. B. P-450 scc activity, in the absence (- - ) or presence (- - $)$ of $15.0 \mu \mathrm{M}$ adrenodoxin. The points shown are the mean of triplicate determinations and are typical of three such experiments.

$[24,25]$ which might be lost upon preparation of the defatted mitochondria. Since this loss would lead to decreased P-450 $11 \beta$ and P-450 scc activities and decreased sensitivity to the inhibition of these activities by the metyrapone analogs, adrenodoxin was purified to approx $90 \%$ homogeneity. The addition of $15.0 \mu \mathrm{M}$ adrenodoxin to this preparation enhanced both P-450 $11 \beta$ and P-450 scc activities (Fig. $1 \mathrm{~A}$ and B). In the presence or absence of adrenodoxin, both activities were linear with time and mitochondrial protein. In this particular preparation, the specific activity of P-450 $11 \beta$ and $P-450$ scc was 2,906.9 and 2,761.9 units/mg mitochondrial protein, respectively, in the presence of $15.0 \mu \mathrm{M}$ adrenodoxin. The addition of trilostane, an inhibitor of $3 \beta$-hydroxysteroid dehydrogenase [28], to the reaction mixtures of $\mathrm{P}$ 450 scc did not affect the activity with time, and further metabolism of the pregnenolone formed was not detected with this preparation.

\section{Effect of various organic solvents}

Since the inhibitors to be studied are lipophilic, especially compound $\mathbf{4}$, an organic vehicle was necessary to deliver the inhibitors into the reaction mixtures. As shown in Figs 2A and B, the addition of ethanol, $N, N$-dimethylformamide and $n$-propanol decreased both P-450 $11 \beta$ and P-450 scc activities. The addition of propylene glycol was well tolerated in the P-450 scc activity assay, but it markedly decreased $\mathrm{P}-450_{11 p}$ activity at concentrations greater than $3 \%$. $N$-Propanol and several other organic solvents were observed to be poorly tolerated and similarly decreased both enzymatic activities to $20 \%$ of the control levels at concentrations of $2 \%$. Since ethanol was slightly better tolerated than $N, N$-dimethylformamide in both assays, it was selected as the organic vehicle. Ethanol, at $1 \%$, gave 92 and $100 \%$ of the control assays for $\mathrm{P}-450_{11 \beta}$ and $\mathrm{P}-450 \mathrm{scc}$ respectively in the absence of added organic solvent. No differences were observed in the presence or absence of $15.0 \mu \mathrm{M}$ adrenodoxin.

\section{Determination of the kinetic constants}

As further evidence that this crude preparation could be used to study the inhibition of both activities, we determined the apparent $K_{\mathrm{m}}$ of DOC for P-450 $11 \beta$ was $6.8 \mu \mathrm{M}$ (Fig. 3A), and the apparent $K_{\mathrm{m}}$ of cholesterol for P-450 scc was $21.6 \mu M$ (Fig. 3B).

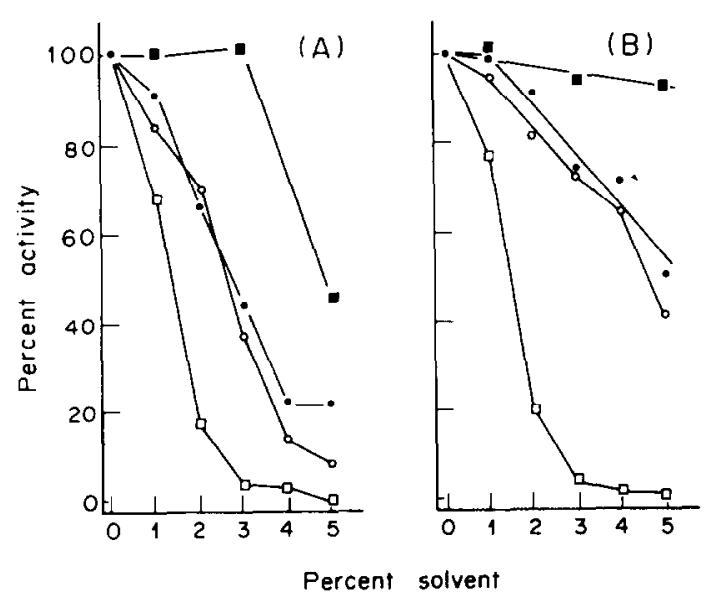

Fig. 2. Effect of various organic solvents on bovine adrenal cortical P-450 ${ }_{11 \beta}$ and P-450 scc activities. Effect of propylene glycol ( $-\square)$, ethanol (-O-), dimethylformamide (-O-), and $n$-propanol (- $\square-$ ) on: A. P-450 $11 \beta$ activity, and B. P-450 scc activity. The points shown are the mean of triplicate determinations and are typical of three such experiments. 

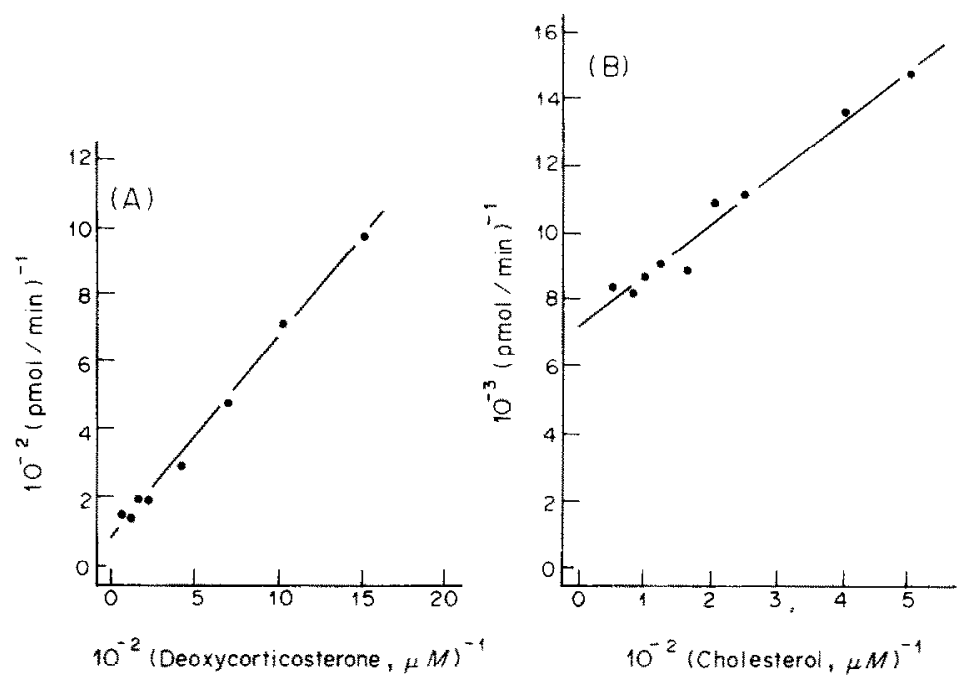

Fig. 3. Determination of the apparent $K_{\mathrm{m}}$ of DOC for P-450 assay conditions were used in the presence of $1 \%$ ethanol. A. Effect of varying the concentration of DOC on P-450 $11 \beta$ activity. B. Effect of varying the concentration of cholesterol on P-450 sce activity. The points shown are the mean of duplicate determinations and are typical of three such experiments.

Although adrenodoxin has been reported to be an effector of cholesterol binding as well as an electron carrier [29], we did not observe the addition of $15.0 \mu \mathrm{M}$ adrenodoxin to affect the $K_{\mathrm{m}}$ of cholesterol or the $K_{\mathrm{m}}$ of DOC in this system.

\section{Inhibition studies}

The inhibition of both P-450 $11 \beta$ and P-450 sce activities by metyrapone, A-phenylmetyrapone, B-phenylmetyrapone, and diphenylmetyrapone is shown in Table 1. P-450 $11 \beta$ activity was 1.3 to 42.3-fold more sensitive to the inhibition by the four metyrapone analogs than P-450 sce activity as shown by the $\mathrm{IC}_{50}(\mu \mathrm{M})$ values. Both enzyme activities require a pyridyl ring for inhibition. The B-pyridyl ring of metyrapone is required for inhibition of both cytochrome P-450s whereas the requirement for the A-pyridyl ring is less stringent. Similar results were obtained in the presence or absence of $15.0 \mu \mathrm{M}$ adrenodoxin.

\section{DISCUSSION}

We have focused on the adrenocortical P-450 $11 \beta$ enzyme system for the development of a radioiodinated inhibitor which would selectively concentrate into the adrenal cortex based on selective inhibition of $\mathrm{P}-450_{11 \beta}$ activity. Although metyrapone will inhibit other cytochrome $P-450$ requiring enzyme systems $[3,7,9-13]$, radiolabeled metyrapone should concentrate in the adrenal cortex due to: (1) a higher concentration of cytochrome P-450 in the adrenal cortex than in the liver or kidney [30], and (2) apparent specificity in vivo and in vitro for $\mathbf{P}$ $450_{1 \beta}[1,2,3,7]$. Tissue distribution studies with tritiated metyrapone have further supported this hypothesis [31]. Since we are interested in developing a radioiodinated metyrapone analog, we initiated a program to systematically alter one region of the metyrapone molecule at a time to determine an optimal site for iodine incorporation while still maintaining a selective inhibition of $\mathrm{P}-450_{11 \beta}$ activity to that of P-450 scc activity. In this study, we synthesized three metyrapone analogs (Table 1) to determine the requirement of the A- or B-pyridyl ring for inhibition of P-450 $11 ;$ and P-450 sce activities.

Several studies were done to characterize the crude, defatted bovine adrenal cortical mitochondrial preparation that was used to evaluate these inhibitors. The enhancement of both activitics by the addition of $15.0 \mu \mathrm{M}$ adrenodoxin (Fig. IA and B) suggests that considerable adrenodoxin is lost upon preparation of the defatted mitochondria. This is consistent with the observations that adrenodoxin is a loosely bound mitochondrial protein $[24,25]$. The effect of organic solvents was investigated (Fig. 2A and B), not only because an organic vehicle is necessary to deliver the inhibitors into the reaction mixtures, but also because organic solvents were reported to affect hepatic cytochrome P-450 binding with hydrocarbon substrates [32]. The decreased activity observed may be the result of an interaction of the organic solvent with either or both the mitochondrial preparation and the substrates DOC and cholesterol. In one study, $12 \mathrm{mg}$ of a similar mitochondrial preparation without added adrenodoxin was used to evaluate the inhibition of $P-450_{11 \beta}$ activity with several metyrapone analogs where the inhibitors, as well as DOC, were delivered in ethanol to give a final concentration of $4 \%$ ethanol [14]. This concentration of ethanol drastically reduced the P-450 $11 \beta$ and P-450 scc activities in our assays. We selected $1 \%$ ethanol, $15.0 \mu \mathrm{M}$ adrenodoxin, and $300 \mu \mathrm{g}$ of the crude, defatted mitochondrial preparation for these studies to minimize 
the potential nonspecific binding of the inhibitors to the mitochondrial preparation and the organic interaction with the inhibitors, substrates and/or mitochondrial preparation. The observed apparent $K_{\mathrm{m}}$ of $6.8 \mu \mathrm{M}$ for DOC for $\mathrm{P}^{-450_{11 \beta}}$ (Fig. 3A) is similar to that reported by others $[3,14]$. The observed apparent $K_{\mathrm{m}}$ of $21.6 \mu \mathrm{M}$ for cholesterol for $\mathrm{P}-450 \mathrm{scc}$ (Fig. 3B) differs from previous reports of $120 \mu \mathrm{M}$ [6], $1.8 \mu \mathrm{M}$ [33] and $5 \mu \mathrm{M}$ [34] which may be due to the mitochondrial preparation used as well as the assay conditions [29].

There is limited information on the inhibition of P-450 scc by metyrapone while the evidence regarding the requirement of both pyridine rings in metyrapone for inhibition of $\mathrm{P}-450_{\sharp \mid \beta}$ is not conclusive. A recent analysis of the crystal and molecular structure of metyrapone can not be used to predict which ring is important for inhibition [35], and previous studies simultaneously modified more than one structural feature of the metyrapone molecule $[14,36]$. This study is a systematic evaluation of the requirement of the pyridine rings (Table 1). The inhibition of $\mathrm{P}$ $450_{11 \beta}$ and $\mathrm{P}-450$ scc activities by these metyrapone analogs demonstrates a requirement for at least one pyridyl ring since diphenylmetyrapone is the poorest inhibitor of both activities. Since the inhibition of P- $450_{11 \beta}$ activity by B-phenylmetyrapone was 8- to 19-fold less effective than A-phenylmetyrapone or metyrapone, the B-pyridyl ring of metyrapone is required for inhibition of $\mathrm{P}-450_{1 i \beta}$ activity whereas the requirement for the A-pyridyl ring is not as stringent. The greater effectiveness of Aphenylmetyrapone to inhibit P-450 sce activity also suggests a requirement of the B-pyridyl ring of metyrapone for inhibition. The similar effectiveness of metyrapone and B-phenylmetyrapone to inhibit P$450 \mathrm{scc}$ activity contrasts to their effectiveness to inhibit $\mathrm{P}-450_{11 \beta}$ activity. This may be due to a greater requirement for a hydrophobic region in the metyrapone molecule to bind to the active site of the cytochrome P-450 scc. The 1.3- to 42.3-fold greater sensitivity of $\mathrm{P}-450_{11 \beta}$ activity than $\mathrm{P}-450 \mathrm{scc}$ activity to the inhibition of metyrapone and its $\mathrm{A}$ - and B-phenyl analogs may also reflect differences in the hydrophilicity of the two active-sites.

These studies suggest some of the structural requirements of metyrapone for the inhibition of $\mathrm{P}-450_{11 \beta}$ and $\mathrm{P}-450 \mathrm{scc}$ activities and suggest that the A-phenylmetyrapone analog is a good candidate for radioiodination as a selective radiopharmaceutical agent for the adrenal cortex. Such an agent could be useful in evaluating patients with defective $\mathrm{P}-450_{11 \beta}$ $[37,38]$.

Acknowledgements - This work was supported by Grant No. CA-09015, Cancer Research Training in Nuclear Medicine, and Grant No. CA-32878 from the N.C.I. and Grant No. AM-21477 from N.I.A.M.D.D., DHEW; by D.O.E. Contract No. DE-AG02-76EV02031 and by the Nuclear Medicine Research Fund.

The authors thank Ms Linder Markham for help in preparing the manuscript. The authors also thank the Phoenix Memorial Laboratory at the University of Michigan for the use of their radiochemistry facilities.

\section{REFERENCES}

1. Temple T. E. and Liddle G. W.: Inhibitors of adrenal steroid biosynthesis. A. Rev. Pharmac. 10 (1970) 199-218.

2. Gower D. B.: Modifiers of steroid-hormone metabolism: A review of their chemistry, biochemistry and clinical applications. J. steroid Biochem. 5, (1974) 50l-523.

3. Sato H., Ashida N., Suhara K., Itagaki E., Takemori S. and Katagiri M.: Properties of an adrenal cytochrome P-450 ( $\left.\mathrm{P}-450_{11 \beta}\right)$ for the hydroxylations of corticosteroids. Archs biochem. Biophys. 190 (1978) 307-314.

4. Suhara K., Gomi T., Sato H., Itagaki E., Takemori S. and Katagiri M.: Purification and immunochemical characterization of the two adrenal cortex mitochondrial cytochrome P-450-proteins. Archs biochem. Biophys. 190 (1978) 290-299.

5. Watanuki M., Tilley B. E. and Hall P. F.: Cytochrome P-450 for $11 \beta$ - and 18-hydroxylase activities of bovine adrenocortical mitochondria: One enzyme or two? Biochemistry 17 (1978) 127-130.

6. Takikawa O., Gomi T., Suhara K., Itagaki E., Takemori S. and Katagiri M.: Properties of an adrenal cytochrome P-450 (P-450 scc) for the side chain cleavage of cholesterol. Archs biochem. Biophys. 190 (1978) 300-306.

7. Sprunt J. G., Browning M. C. K. and Hannah D. M.: Some aspects of the pharmacology of metyrapone. $J$. Endocr. 41 (1968) 193-201.

8. Sindler B. H., Griffing G. T. and Melby J. C.: The superiority of the metyrapone test versus the high-dose dexamethasone test in the differential diagnosis of Cushing's Syndrome. Am. J. Med. 74 (1983) 657-662.

9. Mock D. M., Bruno G. V., Griffin B. W. and Peterson J. A.: Inw temperature EPR spectroscopic characterization of the interaction of cytochrome P-450 cam with a spin label analog of metyrapone. J. biol. Chem. 257 (1982) 5372-5379.

10. Parkinson A., Robertson L. W. and Safe S.: Binding of metyrapone to dithionite-reduced cytochrome P-450 from rats treated with xenobiotics. Biochem. Pharmac. 31 (1982) 3489-3494.

11. Satre M. and Vignais P. V.: Steroid $11 \beta$-hydroxylation in beef adrenal cortex mitochondria. Binding affinity and capacity for spccific $\left[{ }^{14} \mathrm{C}\right]$ steroids and for $\left[{ }^{3} \mathrm{H}\right]$ metyrapol, an inhibitor of the $11 \beta$-hydroxylation reaction. Biochemistry 13 (1974) 2201-2209.

12. Peterson J. A., Ullrich V. and Hildebrandt A. G.: Metyrapone interaction with Pseudomones putida cytochrome P-450. Archs biochem. Biophys. 145 (1971) 531-542.

13. Wilson L. D., Oldham S. B. and Harding B. W.: Studies on adrenal cortical cytochrome P-450. II. Effects of inhibitors of $11 \beta$-hydroxylation on its optical and magnetic propertics. Biochemistry 8 (1969) 2975-2981.

14. Napoli J. L. and Counsell R. E.: New inhibitors of steroid $11 \beta$-hydroxylase. Structure-activity relationship studies of metyrapone-like compounds. $J$. med. Chem. 20 (1977) 762-766.

15. Dominguez O. V. and Samuels L. T.: Mechanism of inhibition of adrenal steroid $11 \beta$-hydroxylase by methopyrapone (metopirone). Endocrinology 73 (1963) 304-309.

16. Liddle G. W., Island D., Lance E. M. and Harris A. P.: Alteration of adrenal steroid patterns in man resulting from treatment with a chemical inhibitor of $11 \beta$-hydroxylation. J. clin. Endocr. Metab. 18 (1958) 906-612. 
17. Levy H., Cha C. H. and Carolo J. J.: The inhibition by metopirone of $11 \beta$ - and 19-hydroxylations of 11-deoxycorticosol in bovine adrenal perfusion. Steroids 5 (1965) 469-478.

18. Greiner J. W., Kramer R. E. and Colby H. D.: Interaction of metyrapone with adrenal microsomal cytochrome P-450 in the guinea pig. Biochem. Pharmac. 27, (1978) 2147-2151.

19. Hays S. J., Tobes M. C., Gildersleeve D. L., Wieland D. M. and Beierwaltes W. H.: Structure-activity relationship study of the inhibition of adrenal cortical $11 \beta$-hydroxylase by new metyrapone analogues. $J$. med. Chem. 27 (1984) 15-19.

20. Landgrebe J. A. and Kirk A. G.: Group migrations to carbene centres. Pyrolysis of the sodium salts of $\alpha$-arylisobutyrophenone tosylhydrazones. $J$. Org. Chem. 32 (1967) 3499-3506.

21. Burger A. and Walter Jr C. R.: Some $\alpha$-substituted $\beta$-pyridylethylamines. $J$. Am. chem. Soc. 72 (1950) 1988-1990.

22. Nedergaard J. and Cannon B.: Overview-preparations and properties of mitochondria from different sources. Meth. Enzym. 55, (1979) 3-28.

23. Peterson G. L.: A simplification of the protein assay method of Lowry et al. which is generally applicable. Analyt. Biochem. 83 (1977) 346-356.

24. Kimura T. and Suzuki K.: Components of the electron transport system in adrenal steroid hydroxylase. Isolation and properties of non-heme iron protein (adrenodoxin). J. biol. Chem. 242 (1967) 485-491.

25. Kimura T., Parcells J. H. and Wang H-P.: Purification of adrenodoxin reductase, adrenodoxin, and cytochrome P-450 from adrenal cortex. Meth. Enzym. 52, (1978) 132-142.

26. Hanukaglu I. and Jefcoate C. R.: Mitochondrial cytochrome P-450 scc mechanism of electron transport by adrenodoxin. J. biol. Chem. 255 (1980) 3057-3061

27. Hanukaglu I. and Jefcoate C. R.: Pregnenolone separation from cholesterol using Sephadex LH-20 minicolumns. J. Chromat. 190 (1980) 256-262.

28. Shears S. B. and Boyd G. S.: The effect of azastene, cyanoketone and trilostane upon respiration and cleavage of the cholesterol side chain in mitochondria from bovine adrenal cortex. Eur. J. Biochem. 117 (1981) 75-80.

29. Hanukaglu I., Spitsberg V., Bumpus J. A., Dus K. M and Jefcoate $\mathrm{C}$. R.: Adrenal mitochondrial cytochrome $P-450$ scc. Cholesterol and adrenodoxin interactions at equilibrium and during turnover. $J$. biol. Chem. 256 (1981) 4321-4328.

30. Wickramsinghe R. II.: Biological aspects of cytochrome P-450 and associated hydroxylation reactions. Enzyme 19 (1976) 348-376.

31. Beierwaltes W. H., Wieland D. M., Ice R. D., Seabold J. E., Sarkar S. D., Gill S. P. and Mosely S. T.: Localization of radiolabeled enzyme inhibitors in the adrenal glands. J. Nucl. Med. 17 (1976) 998-1002.

32. Backes $W$. L. and Canady $W$. J.: The interaction of hepatic cytochrome P-450 with organic solvents. The effect of organic solvents on apparent spectral binding constants for hydrocarbon substrates. J. hiol. Chem. $\mathbf{2 5 6}$ (1981) $7213-7227$.

33. Greenfield N. J., Gerolimatos B., Szwergold B. S., Wolfson A. J., Prasad V. V. K. and Lieberman S.: Effects of phospholipid and detergent on the substrate specificity of adrenal cytochrome P-450 scc. Substrate binding and kinetics of cholesterol side-chain oxidation. J. biol. Chem. 256 (1981) 4407-4417.

34. Wolfson A. J. and Lieberman S.: Evidence suggesting that more than one sterol chain cleavage enzyme system exists in mitochondria from bovine adrenal cortex. J. biol. Chem. 254 (1979) 4096-4100.

35. Rossi M.: Structural studies of metyrapone: A potent inhibitor of cytochrome P-450. J, med. Chem. 26 (1983) 1246-1252.

36. Kahnt F. W. and Neher R.: Modifikationen der Nebennierenrindenfunktion in vitro durch 3- and 4-pyridine derivate. Experientia 27 (1971) 959-961.

37. Guthrie G. P., Wilson E. A., Quillen D. L. and Jawad $M$. J.: Adrenal androgen excess and defective $11 \beta$-hydroxylation in women with idiopathic hirsutism. Arch. Intern. Med. 142 (1982) 729-735.

38. Zachmann M., Tassinari D. and Prader A.: Clinical and biochemical variability of congenital adrenal hyperplasia due to $11 \beta$-hydroxylase deficiency. A study of 25 patients. J. clin. Endocr. Metab. 56 (1983) 222-229. 